\title{
Regeringsautonomi og delegeringstab i dansk EU-politik \\ Et principal-agent teoretisk perspektiv
}

\author{
Rasmus Brun Pedersen Adjunkt, Institut for Statskundskab, Århus Universitet
}

Får Folketinget den indflydelse på EU-politikken som det skal have? Artiklen opstiller en model som søger at analysere det relative niveau af aktørindflydelse. Analysen tegner et billede af at regeringer har et vist råderum til at udnytte forhandlingerne til at realisere resultater der ligger tættere på deres egne præferencer, men at Folketingets partier ligeledes har muligheder for at udøve uforholdsmæssig stor indflydelse på enkelte delområder.

\section{Introduktion}

Har Folketinget den indflydelse på EU-politikken, som det skal have, og hvem bestemmer indholdet i den danske EU-politik? Oftest høres det i forbindelse med traktatforhandlinger, at den danske regering forsvarer resultatet med, at det har været i den 'danske interesse'. Tilsvarende forsvarer oppositionen ofte sin støtte til den samlede traktattekst med, at den har været i stand til at sætte betydelige 'fingeraftryk' på de endelige resultater. Hovedparten af de studier, som har analyseret dansk europapolitik, har fokuseret på den konkrete forhandlingsfase, hvor den 'nationale interesse' udtrykt gennem forhandlingspositioner forhandles af regeringen på EU-niveau og af selve forløbet af regeringskonferencerne (Laursen 1992; 1994a; 1994b). Der er imidlertid langt færre studier, som systematisk har søgt at analysere, hvordan de nationale forhandlingspositioner dannes og formes nationalt, og fokuseret på hvilke parlamentariske aktører, der faktisk vinder og taber i forbindelse med den danske positionsdannelse og under regeringens interessevaretagelse i de efterfølgende traktatforhandlinger. En central årsag hertil er, at vi mangler kriterier og modeller, der kan analysere det relative niveau af aktørindflydelse på de nationale forhandlingspositioner og på de endelige forhandlingsresultater. Der skrives imidlertid meget om 'parlamentarisk afkobling' og øget regeringsautonomi i den europæiske integrationsproces, hvilket bl.a. har ledt til argumenter om demokratisk underskud grundet manglende parlamentarisk kontrol og indflydelse på de nationale regeringers forhandlingsadfærd i samarbejdet (Maurer \& Wessels 2001; Anderson 2002; Goetz 2005; Börzel \& Risse 2006). Argumentet synes at være, at de parlamentariske aktører udøver et lavere niveau af indflydelse på politikudformningen som følge af EU's intergovernmentelle forhandlingsstruktur, end de gør på almindelig national lovgivning (Raunio 1999;2005; Raunio \& Hix 2000; Maurer et al 2003). Det hænger sammen med, at forhandlingsstrukturen giver regeringerne en række ressourcemæssige fordele, som typisk udmøntes i asymmetrisk adgang til information (Poguntke $\&$ Webb 2005). Antagelsen er, at informationsfordelene anvendes til at forfølge 'policy drifts', dvs. at regeringerne udøver et højere niveau af indflydelse på forhandlingsområderne, end de ville være i stand til, hvis de ikke havde disse informationsfordele. Disse dynamikker har ledt til argumenter om demokratisk underskud i det europæiske samarbejde, her forstået som en reduktion i den nationale parlamentariske kontrol med regeringen. En problemstilling, som synes særligt relevant for regeringskonferenceforhandlinger, som definerer de grundlæggende konstitutionelle rammer for samarbejdet.

Problemet er dog både af empirisk og teoretisk karakter. Empirisk ved vi således meget lidt om, hvad de nationale parlamentariske aktører faktisk ønsker sig i de komplicerede regeringskonferenceforhandlinger. Dette 
besværliggør selvsagt en vurdering af hvilke nationale parlamentariske aktører, som faktisk vinder og taber i de europæiske traktatforhandlinger. Teoretisk er udfordringen, at litteraturen i et vist omfang har forsømt at udvikle analytiske redskaber til systematisk at konceptualisere og måle omfanget af dette påståede underskud (Raunio \& Hix 2000). Spørgsmålet er selvsagt også, hvordan dette lidt kontrafaktiske argument i litteraturen kan undersøges. Artiklen her præsenterer en analytisk model, som søger at oversætte de teoretiske indsigter om parlamentarisk afkobling og regeringsautonomi til et principalagentteoretisk sprog. Derved bliver det muligt at foretage en direkte sammenligning af det forventede niveau af parlamentarisk indflydelse på de danske forhandlingspositioner og en sammenligning med det realiserede niveau af parlamentarisk indflydelse på de danske positioner og de endelige forhandlingsresultater under antagelser om fuld og asymmetrisk information. ${ }^{1}$ Dette muliggør en mere systematisk vurdering af hvilke nationale aktører, der kan siges at vinde og tabe, når den danske regering forhandler i det europæiske samarbejde.

\section{Parlamentarisk afkobling som et delegeringsproblem}

Den parlamentariske litteratur og europæiseringslitteraturen peger ofte på en systematisk tendens til styrkelse af regeringerne vis-a-vis de nationale parlamenter i det europæiske samarbejde (jf. Raunio \& Hix 2000). Argumentet er, at der er tegn på en stigende afparlamentarisering af medlemsstaternes EU-politik, fordi EU's forhandlingsstruktur giver de nationale regeringer særlige forhandlingsfordele. Logikken er, at strukturens intergovernmentelle karakter afkobler det nationale parlaments indflydelse. Dette giver de nationale regeringer en række informationsfordele, som de kan bruge til at udøve et relativt højt niveau af indflydelse på forhandlingspositionerne i den europæiske integrationsproces (Raunio 1999; 2005; Raunio \& Hix 2000; Maurer \& Wessels 2001). Resultatet er, at regeringerne bliver i stand til at dominere indholdet af staters forhandlingspositioner $i$ det europæiske samarbejde og derved påvirke de endelige traktatudfald (jf. Maurer \& Wessels 2001; Anderson 2002). ${ }^{2}$

Derved tvinges parlamentet til at acceptere resultater, som ligger tættere på regeringernes egne præferencer end det, parlamentet ville have accepteret, hvis der havde eksisteret fuld information om forløbet af disse forhandlinger (Follesdal 1998; 2000; Poguntke \& Web 2005). Mens fordelen ved europæiseringslitteraturen er, at den relativt parsimonisk har været i stand til at integrere en række udviklingstendenser i en samlet teoretisk forklaringsramme, har den været relativt tavs omkring, hvordan de observerbare implikationer af dette informationsargument kan analyseres og oversættes til konkrete og empirisk testbare hypoteser om omfanget af den forventede parlamentariske afkobling i EU-samarbejdet.

Artiklens argument er, at en række af disse forventninger kan analyseres ved hjælp af principal-agentteorien (PA). PA-litteraturen tillader os således at 'oversætte' disse til konkrete testbare hypoteser om, hvilket indflydelsesmønster vi kan forvente på forhandlingspositionerne og -resultaterne i den europæiske integrationsproces. 'Fuld information' svarer til en situation, hvor der er fuld information mellem regering og parlament om aktørernes præferencestrukturer samt om udviklingen og karakteren af den pågældende forhandlingssituation. 'Asymmetrisk information' betyder her, at der ikke er fuld information mellem de to aktører om forløbet af den pågældende internationale forhandlingsrunde.

Det antages i PA-analyser, at 'regeringen' agerer i rollen som agent, og 'parlamentet' agerer i rollen som principal. En situation, som netop er relevant i et system som det danske, hvor regeringen handler på vegne af Folketingets mandatgivning i EU-sammenhæng. I det følgende betegnes den danske regering som agenten, mens Folketinget agerer som principal. En oplagt forklarende faktor i parlamentariske demokratier er, at indflydelse på forhandlingspositionen vil reflektere det parlamentariske flertals præferencer. Forhandlingslitteraturen betegner traditionelt dette parlamentariske flertal som den parlamentariske pivotalaktør (Hug \& König 2002). Agenten svarer til den til enhver tid siddende regering, mens principalen svarer til den parlamentariske pivotalaktør, dvs. den parlamentariske aktør, som kræves for at sikre, at regeringen ikke har et flertal imod sig, og som derved kan sikre ratificering af den endelige forhandlingsaftale (Hug \& König 2002). I den empiriske analyse optræder den borgerlige mindretalsregering som agent, mens Socialdemokratiet i opposition optræder i rollen som den parlamentariske pivotalaktør, da dette parti traditionelt har indtaget en dominerende position i den danske europapolitik (jf. Petersen 1991; 1995; 2006).

\section{Hvad er informationsasymmetri?}

I det følgende analyseres de forventede effekter af den type informationsasymmetri, der i forhandlingslitteraturen betegnes som 'moral hazard' med skjult information. 'Moral hazard' refererer til, at agenten og principalen typisk lægger ud med et symmetrisk informationsniveau om karakteren af hinandens præferencer. I takt med at de konkrete forhandlinger skrider frem, antages det, at kompleksitetsniveauet som følge af forhandlingerne 
øges. Derved stiger principalens omkostninger ved at opdatere information, da denne ikke er direkte involveret i de internationale forhandlinger og derved har en reduceret mulighed for at vurdere troværdigheden af den information, den modtager om forhandlingerne. Dette medfører, at regeringen i rollen som agent, qua dens informationsfordel, er i stand til at udøve autonomi over forhandlingspositionen og derved udføre handlinger og tage beslutninger, som parlamentet vanskeligt kan overvåge (Strøm 2000, 270-71; Lupia 2003). Asymmetrisk information antages at påvirke aktørernes mulighed for at realisere deres ønsker i forhandlingerne. Informationsfordele gør det således teoretisk nemmere for agenten at manipulere med principalen og udøve et højere niveau af autonomi under forhandlingerne.

'Moral hazards' medfører således 'delegeringstab', når regeringen får mulighed for at foretage handlinger - dvs. udøve autonomi - på positioner og resultater, som principalen ellers ikke ville have accepteret (Kiewiet \& McCubbins 1991, 25-27). ${ }^{3}$

\section{Hvad er delegeringstab?}

Delegeringstab beskrives her som forskellen mellem de forventede og de realiserede resultater af en delegeringshandling mellem agenten og principalen, hvis agenten havde ageret som en 'perfekt' agent. 'Perfekt' betyder her det niveau af indflydelse, som principalen ville have haft, hvis denne havde ubegrænset adgang til information og ressourcer til at kontrollere agenten. Forskellen - eller tabet - beskriver niveauet af agentens autonomi i en delegeringshandling set fra principalens synspunkt. Når autonomien er høj, betyder det, at resultatet placerer sig langt væk fra principalens idealpunkt (P). Hvis niveauet er lavt, forventer modellen, at resultatet placerer sig tættere på $\mathrm{P}$. Tabet er 0 , hvis agenten foretager handlinger, som principalen selv ville have valgt. 'Delegeringstab' korresponderer med en række af de indsigter, som har været fremført om parlamentarisk afkobling. Litteraturen har ikke eksplicit drøftet betydningen af de såkaldt 'naturlige' transaktionsomkostninger, som altid vil eksistere i politiske forhandlinger, og om disse kan siges at være højere, når regeringer forhandler internationalt end i forhold til 'normal' national politik. Modellen tager dog højde for eksistensen af sådanne 'naturlige' transaktionsomkostninger og viser, hvornår eventuelle tab overstiger det forventede niveau. Et delegeringstab over det forventede niveau vil således betyde en forventning om, at resultatet ikke vil blive accepteret, medmindre der eksisterer asymmetrisk information, hvorved principalen risikerer at fejlvurdere de reelle omkostninger ved forslaget. Delegeringstab korresponderer med argumenterne i europæiseringslitteratu- ren ved, at ethvert 'tab' over det forventede niveau kan betegnes som et tab af 'parlamentarisk indflydelse'.

Det antages i modellen, at agenten beslutter, hvorvidt der skal fremsættes et forslag (X $\varepsilon[0 ; 1])$, som vil lede til et andet resultat, end hvis denne ikke havde foreslået noget; dvs. status quo (SQ $\varepsilon[0 ; 1])$. SQ repræsenterer resultatet af en delegeringshandling, hvor agenten vælger ikke at handle. Efter at agenten har valgt, om denne vil foreslå $\mathrm{X}$ eller bevare SQ, har principalen to muligheder: at acceptere eller afslå X. Et afslag kan enten ses som en form for veto mod agentens forslag eller som en sanktion, som er tilstrækkelig til at overtale - eller tvinge - denne til at ændre sit forslag i en retning, som er acceptabelt for principalen (Lupia 2003). Hver aktør har et idealpunkt på en linje fra $[0 ; 1]$. Det antages, at hver aktør søger at maksimere sine præferencer i en 'single-peaked' nyttefunktion. 'Toppen' af hver aktørs nyttefunktion kan betegnes som aktørens idealpunkt. Efter at agenten har fremsat et forslag (X eller SQ), vil de to aktørers nytte være bestemt af den spatielle distance mellem det udspil, som principalen accepterer (X eller SQ), og de to aktørers idealpunkter (A og P). De to aktører foretrækker forslag, hvor X eller SQ ligger tættest på de respektive idealpunkter, da de søger at maksimere deres nytte i forhandlingerne. Principalens idealpunkt er $\mathrm{P} \varepsilon[0 ; 1]$, og agentens idealpunkt er A $\varepsilon[0 ; 1]$. Modellens centrale antagelse under fuld information er, at aktørerne har fuldstændig information om placeringen af A og P. Givet konstellationen af aktørernes idealpunkter (placeringen af A og $\mathrm{P}$ på en single-peaked nyttekurve) kan vi relativt nemt udlede hypoteser om det optimale udfald af aktørernes forhandlinger og om omfanget af delegeringstab. Det antages endvidere, at principalen kun kan acceptere eller afslå agentens forslag.

\section{Hypoteser om aktørindflydelse}

Analysens udgangspunkt er, at variationen i aktørernes indflydelse kan anvendes til at udlede hypoteser om niveauet af aktørindflydelse på forhandlingspositionerne under antagelser om fuld og asymmetrisk information. Logikken er, at vi kan udlede testbare hypoteser om udfaldet på de enkelte forhandlingsområder, hvis vi kender agentens og principalens præferencer. ${ }^{4}$ I det følgende opstilles der på linje med Lupia (1992) fire forskellige konstellationer af præferencer mellem agent og principal, som der kan udledes testbare hypoteser på baggrund af. ${ }^{5}$ Operationaliseringen af præferencekonstellationer fokuserer på i alt tre relevante variable: SQ definerer status quo, dvs. det traktatmæssige grundlag, der skal forhandles om. A repræsenterer agentens idealpunkt, mens $P$ repræsenterer principalens idealpunkt. 


\section{Konstellation 1}

I den første situation antages det, at der ikke er konflikt mellem aktørerne, og at agenten (A) og principalen (P) har identiske idealpunkter. Vi kan derfor forvente, at de to aktører er enige om, hvilken position man skal fremme i de kommende forhandlinger. Ligevægten $\left(^{*}\right)$ forventes derfor placeret i $(\mathrm{P}=\mathrm{A})$, da modellen forudsiger, at agenten vil foreslå $\mathrm{A}$, som vil blive accepteret af principalen. I denne situation skulle vi ikke have nogen forventninger om delegeringstab.

$\mathrm{SQ}_{S Q} \mathrm{P}_{\mathrm{P}=\mathrm{A}}^{*}$

\section{Konstellation 2}

I denne situation antages det, at principalens idealpunkter ligger længere væk fra SQ end fra agentens idealpunkt. Det betyder, at principalen foretrækker A frem for SQ. Her vil man forvente, at agenten kræver A, hvilket principalen accepterer, da den foretrækker A frem for SQ. Delegeringstabet bliver i denne situation større end under 1. Dette tab kan betegnes -|A-P|. Der findes endnu en mulighed for, at agenten kan realisere A inden for denne præferencekonstellation. Det vil være tilfældet, hvis A er tættere på SQ end P. De analytiske konsekvenser af denne situation er de samme, da P er tættere på A end på SQ. Denne situation kan illustreres ved, at A1 er tættere på $S Q$, end $P_{1}$ er på $S Q$.

\begin{tabular}{llllllll}
\multicolumn{4}{c}{} & & & \\
& ${ }^{*}{ }_{1}$ & & & \\
\hline & & & & & & \\
$S Q$ & $A_{1}$ & & $P_{1}$ & $P$ & $A$
\end{tabular}

\section{Konstellation 3}

Her antages det, at begge aktørers idealpunkter ligger på den samme side af SQ. Dette betyder, at de to aktører er enige om den ønskede retning men uenige om omfanget af en politikændring. P er tættere på SQ end på A, og foretrækker således SQ frem for A. Da A ved dette, vil han ikke søge at realisere $A$, men vil derimod vælge en anden strategi og foreslå et alternativ. I ligevægt vil agenten derfor fremsætte det forslag, som ligger tættest på hans eget idealpunkt, som principalen vil acceptere. Dette holder, når $\mathrm{SQ}>\mathrm{A}$ og $\mathrm{P}$, da regeringen vil foreslå $\mathrm{P}$ - (SQ-P) $+\varepsilon$, hvor $\varepsilon>\mathrm{O}$. Hvis $\mathrm{SQ}<\mathrm{A}$ og $\mathrm{P}$, vil regeringen foreslå $\mathrm{P}$ $+(\mathrm{SQ}-\mathrm{P})-\varepsilon$. Delegeringsomkostningerne vil være mindst lige så store eller større end tabet i de øvrige situationer og kun lige akkurat mindre end distancen mellem SQ og P. Delegeringstabet kan under fuld information betegnes som -(SQ-P) - $\varepsilon$. Delegeringstabet er i denne situation mindst lige så stort eller større end delegeringsomkostningerne i konstellation 1 og 2.

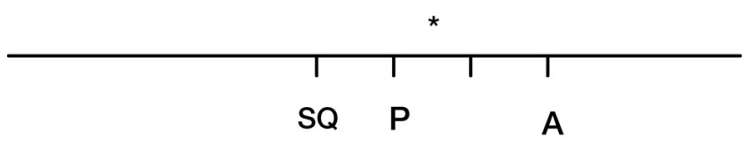

\section{Konstellation 4}

I denne situation antages det, at idealpunkterne A og $\mathrm{P}$ symmetrisk placerer sig på hver sin side af SQ. Dette svarer til, at principalen ikke ønsker at introducere nye tiltag i det europæiske samarbejde eller at få fjernet eksisterende elementer eller forslag på forhandlingsdagsordenen. Agenten ønsker på den anden side at introducere de nye tiltag. I denne situation er der ikke nogen mulighed for at opnå et fælles resultat for både parlamentet og regeringen. Ud fra antagelserne om fuld information ville man her forvente, at resultatet af interaktionen ville være SQ og delegeringsomkostningerne dermed defineret som distancen mellem SQ og P.

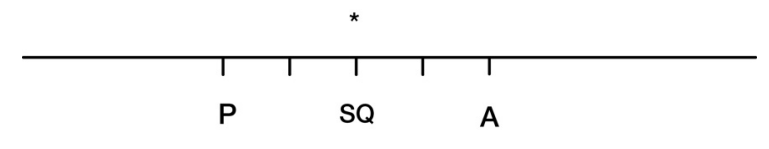

Når man bevæger sig fra konstellation 1 til 4, medfører det enten en stigning i distancen mellem A og P eller en stigning i distancen mellem $P$ og SQ relativt til distancen mellem A og P. Sagt på en anden måde: Hvis agentens idealpunkt eller SQ bevæger sig væk fra principalens idealpunkt, forøges delegeringstabet, og risikoen for omkostninger for principalen stiger. Dette er med til at øge det potentielle konfliktniveau, da omkostningerne for de involverede parter er stigende i tilfælde af, at man fejlkalkulerer placeringen af modpartens idealpunkt. At delegeringstabet kan vokse med distancen mellem $\mathrm{P}$ og SQ, følger af det forhold, at et dårligt SQ gør en bredere vifte af forslag attraktive for principalen.

Modellens hypoteser er opsummeret i Tabel 1. Her er de forventede udfald og omfanget af delegeringstab under fuld information sammenlignet med det forventede niveau under asymmetrisk information. 'Forventet delegeringstab' svarer til det tab af indflydelse, som principalen forventes at lide på de forskellige forhandlingsområder givet de indbyggede delegationsomkostninger, der eksisterer i enhver delegationshandling. Tabet afspejler således det niveau af politiske omkostninger, som principalen vil være villig til at acceptere i enhver forhandling. Kolonnen 'ændringer i delegeringstabet' afspejler den forventede stigning i delegeringsomkostningerne for princi- 
Tabel 1. Hypoteser om aktørindflydelse

\begin{tabular}{|c|c|c|c|c|}
\hline & \multicolumn{2}{c|}{$\begin{array}{c}\text { Hypoteser } \\
\text { Ingen parlamentarisk afkobling } \\
\text { (fuld information) }\end{array}$} & \multicolumn{2}{c|}{$\begin{array}{c}\text { Hypoteser } \\
\text { Parlamentarisk afkobling } \\
\text { (asymmetrisk information) }\end{array}$} \\
\cline { 2 - 5 } Præference-konstellation & $\begin{array}{c}\text { Forventet } \\
\text { udfald }\end{array}$ & $\begin{array}{c}\text { Forventet } \\
\text { delegationstab }\end{array}$ & $\begin{array}{c}\text { Forventet } \\
\text { udfald }\end{array}$ & $\begin{array}{c}\text { Endring i delegeringstabet i } \\
\text { forhold til fuld information }\end{array}$ \\
\hline 1 & $\mathrm{P}=\mathrm{A}$ & 0 & $\mathrm{SQ}$ & $|\mathrm{P}-\mathrm{SQ}|$ \\
\hline 3 & $\varepsilon$ tættere på P end på SQ & $-|S Q-P|-\varepsilon$ & $\mathrm{A}$ & $|\mathrm{A}-(|\mathrm{SQ}-\mathrm{P}|+\varepsilon)|$ \\
\hline 4 & $\mathrm{SQ}$ & $-|S Q-P|$ & $\mathrm{A}^{*}$ & $|\mathrm{~A}-\mathrm{SQ}|$ \\
\hline
\end{tabular}

Baseret på Niskanen (1971), Romer \& Rosenthal (1978) samt Lupia (1992; 2003). A* betegner agentens idealpunkt i situationen, hvor hans og principalens idealpunkt er på hver sin side af SQ. I denne situation er A* det værst tænkelige udfald for principalen. $\varepsilon$ udtrykker et nummer, som er større end nul, men meget lille. Bemærk, at - $|\mathrm{X}-\mathrm{P}|$ svarer til principalens givne nytteniveau givet idealpunktet $\mathrm{P}$ og delegeringsresultatet $\mathrm{X}$.

palens synspunkt i tilfælde af parlamentarisk afkobling. Specifikt peger tabellen således på, at delegeringsomkostningerne under asymmetrisk information i alle situationer risikerer at være højere end under fuld information.

\section{Researchdesign, data og metode}

Modellen er anvendt på et såkaldt within-case studie af den danske positionsdannelse i forbindelse med Maasticht-traktaten. I alt analyseres positionsdannelsen på 10 områder, hvor der var formuleret eksplicitte danske forhandlingspositioner forud for konferencen. Disse kom til udtryk i det danske regeringsmemorandum (Regeringen 1990) og det senere danske forhandlingsudspil på konferencen, som juridisk konkretiserede indholdet $\mathrm{i}$ memorandummet (CONF-UP 1777/1/91). ${ }^{6}$

Artiklens analyser baserer sig på et relativt omfattende datagrundlag af primære såvel som sekundære kilder, der belyser præference- og positionsdannelsen på ministerielt, parlamentarisk og partipolitisk plan. ${ }^{7}$ Dette datagrundlag muliggør en relativ præcis vurdering af de respektive aktørers præferencer på de forskellige områder, som fandt vej i de danske forhandlingspositioner.

Analysen har operationaliseret aktørernes præferencer på et endimensionelt politikrum, hvor aktørernes præferencer (A og P) i forhold til 'mere' eller 'mindre' integration på de enkelte delområder, som indgik i forhandlingerne. Estimeringen af aktørernes idealpunkter baserer sig på partiernes partiprogrammer eller andre eksplicitte tilkendegivelser i processen op til forhandlingerne. SQ er estimeret ud fra det eksisterende traktatgrundlag og fra indholdet i de udspil, som dannede grundlag for forhandlingerne på konferencen.

F.eks. er forhandlingerne om Vestunionens (WEU) inddragelse i den Fælles Udenrigspolitik (FUSP) operationaliseret som et område, hvor $\mathrm{P}$ og $\mathrm{A}$ placerer sine idealpunkter på hver sin side af SQ (dvs. situation 4).
Konflikten mellem regering og Folketing gik konkret på, hvorvidt Danmark skulle støtte en udvidelse af WEU's funktion i samarbejdet, og om Danmark skulle deltage i dette samarbejde. Regeringen markerede ved flere lejligheder, at man ønskede en udvidelse af WEU's funktion i EU i forhold til det eksisterende traktatgrundlag, ligesom man var tilhænger af dansk medlemskab (jf. Folketingets forhandlinger 1989/90 spalte 8455ff; 1990/91 spalte 7108-09;7153; 1991/92 spalte 1097-1088, jf. desuden Pedersen, 2009:132-133; 179). Socialdemokratiet udtrykte i modsætning hertil modstand imod inddragelsen af WEU i samarbejdet, ligesom man var modstander af dansk deltagelse i WEU (jf. Folketingets forhandlinger 1990/91 spalte 7107-08 jf. desuden Pedersen, 2009: 173-174; Haahr 1990). Placeringen af SQ er estimeret på baggrund af det eksisterende traktatgrundlag og de foreliggende forhandlingsudspil på konferencen (f.eks. de fransk-tyske og britisk-italienske udspil om WEU's status, som blev forelagt på konferencen jf. Christoffersen, 1992: 248-250).

Rækkevidden af analysens konklusioner kan dog siges at være begrænset af det forhold, at regeringskonferencer primært giver et 'snapshot' af en mere kompleks politisk virkelighed. Logikken er, at de væsentligste udviklinger i relationerne mellem regeringer finder sted i intervallerne mellem regeringskonferencerne, og at analyserne derfor risikerer at fejllæse indflydelsesniveauet på baggrund af én enkelt regeringskonference. Selvom regeringskonferencer meget vel afspejler tidligere trends i magtrelationerne, er der imidlertid ikke grund til at antage, at dette svækker artiklens analytiske konklusioner. Det skyldes, at konstitutionelle reformforhandlinger i en vis forstand fremstår som 'kritiske øjeblikke' i den europæiske integrationsproces, hvis udfald har langtrækkende politiske konsekvenser for relationerne mellem regeringer og parlamenter (jf. Moravcsik 1993; 1998). Netop derfor burde vi forvente, at regeringskonferenceforhandlinger skulle være særligt 
Tabel 2. Aktørpræferencer før konferencen

\begin{tabular}{|c|c|c|c|}
\hline $\begin{array}{c}\text { Præference- } \\
\text { konstellationer }\end{array}$ & Område & Regering & Socialdemokratiet \\
\hline \multirow[t]{3}{*}{1} & $\begin{array}{l}\text { Effektivitet i } \\
\text { institutionerne }\end{array}$ & $\begin{array}{l}\text { - Ingen ændringer i institutionel balance. } \\
\text { - } \text { Øget brug af kvalificerede flertalsafgørelser i Rådet på } \\
\text { miljø- og arbejdsmiljøområdet samt på rammeprogram- } \\
\text { - } \text { merne for forskning og teknologi. } \\
\text { - Reduktion af antallet af kommissærer. } \\
\text { - Mere kontrol med medlemsstaternes efterlevelse af } \\
\text { deres forpligtelser. } \\
\text { - Større fokus på bekæmpelse af svig. } \\
\text { - Forenkling af retsakterne. }\end{array}$ & $\begin{array}{l}\text { - Ingen ændringer i institutionel balance. } \\
\text { - } \text { Øget brug af kvalificerede flertalsafgørelser på miljø- } \\
\text { og arbejdsmiliøområdet samt på rammeprogrammerne } \\
\text { for forskning og teknologi. } \\
\text { - Reduktion af antallet af kommissærer. Mere kontrol } \\
\text { med medlemsstaternes efterlevelse af deres forplig- } \\
\text { telser. } \\
\text { - Større fokus på bekæmpelse af svig. } \\
\text { - Forenkling af retsakterne. }\end{array}$ \\
\hline & Subsidiaritet & - Subsidiaritet som politisk princip. & - Subsidiaritet som politisk princip. \\
\hline & Åbenhed & $\begin{array}{l}\text { - Aktindsigt i EF-lovgivning. } \\
\text { - Etablering af en ombudsmandsfunktion under Parla- } \\
\text { mentet. } \\
\text { - Oprettelse af en særlig komité for regionerne. } \\
\text { - Ret til lokal stemmeret for EU-borgere med bopæl i } \\
\text { udlandet. } \\
\text { - Oprettelse af en særlig komité for regionerne. } \\
\text { - } \text { Øget inddragelse af de nationale parlamenter i } \\
\text { samarbejdet. }\end{array}$ & $\begin{array}{l}\text { - Åbne rådsmøder. } \\
\text { - Aktindsigt i EF-lovgivning. } \\
\text { - Ret til lokal stemmeret for EU-borgere med bopæl i } \\
\text { udlandet. } \\
\text { - Oprettelse af en særlig komité for regionerne. } \\
\text { - Etablering af en ombudsmandsfunktion under } \\
\text { Parlamentet. } \\
\text { - } \text { Oget inddragelse af de nationale parlamenter i } \\
\text { samarbejdet. }\end{array}$ \\
\hline \multirow[t]{3}{*}{2} & Europa-parlamentet & $\begin{array}{l}\text { - } \text { Øget EP-kompetence til at overvåge Kommissionen. } \\
\text { - Accept af øget EP-inddragelse i beslutningsproceduren. }\end{array}$ & $\begin{array}{l}\text { - } \text { Øget EP-kompetence til at overvåge Kommissionen. } \\
\text { - Ingen interesse i at udvide EP's rolle i beslutnings- } \\
\text { processen. }\end{array}$ \\
\hline & $\begin{array}{l}\text { Miljø- og } \\
\text { arbejdsmarkeds- } \\
\text { politik }\end{array}$ & $\begin{array}{l}\text { - Tilhænger af at kvalificerede flertalsafgørelser. } \\
\text { - Opbakning miljøgarantien. }\end{array}$ & $\begin{array}{l}\text { - Indførelse af kvalificerede flertalsafgørelser. } \\
\text { - Bevarelse og styrkelse af den danske miljøgaranti. } \\
\text { - Styrkelse af miljøbeskyttelsesmålsætninger i sam- } \\
\text { arbejdet. }\end{array}$ \\
\hline & Social dimension & $\begin{array}{l}\text { - Ikke klart formulerede positioner men villig til at accep- } \\
\text { tere indskrivning af social dimension. }\end{array}$ & $\begin{array}{l}\text { - Tilhænger af indskrivningen af den sociale dimension } \\
\text { i traktaten. }\end{array}$ \\
\hline \multirow[t]{2}{*}{3} & Kulturpolitik & $\begin{array}{l}\text { - Tilhænger af indskrivning af kulturpolitikken i traktaten. } \\
\text { - Skepsis over for etablering af en fælles kulturel identitet. } \\
\text { - Vægtning af varernes frie bevægelighed over de } \\
\text { - } \text { kulturpolitiske. } \\
\text { - Interesse i at bevare nationale subsidieringsmuligheder. }\end{array}$ & $\begin{array}{l}\text { - Støtte til traktatfæstning forudsat mulighed for } \\
\text { statsstøtte. Undtaget for generelle konkurrence- } \\
\text { bestemmelser. }\end{array}$ \\
\hline & $\emptyset \mathrm{MU}$ & $\begin{array}{l}\text { - Tilhænger af hurtig anden og tredje fase. } \\
\text { - } \text { Ønske om dansk forpligtelse til tredje fase. } \\
\text { - Prisstabilitet som primær målsætning for ØMU. } \\
\text { - Lav interesse i andre målsætninger såsom miljø, energi } \\
\text { og beskæftigelseshensyn for ØMU. }\end{array}$ & $\begin{array}{l}\text { - Tilhænger af første fase. Skepsis imod anden og tredje } \\
\text { fase. } \\
\text { - Imod dansk forpligtelse til at tilslutte sig disse faser. } \\
\text { - Tilhænger af bred målsætning for ØMU, herunder ener- } \\
\text { gipolitiske hensyn samt særlig beskæftigelse og miljø } \\
\text { som ligeværdige hensyn med inflationsbekæmpelse og } \\
\text { prisstabilitet. } \\
\text { - Mindre interesse i prisstabilitet som målsætning. }\end{array}$ \\
\hline \multirow[t]{2}{*}{4} & FUSP & $\begin{array}{l}\text { - Uddybelse af EPS. } \\
\text { - } \emptyset \text { get koordinering mellem institutionerne. } \\
\text { - Bredere ramme for FUSP. } \\
\text { - Accept af flertalsafgørelser under visse betingelser. }\end{array}$ & $\begin{array}{l}\text { - Modstander af udvidelse af EPS til en egentlig FUSP. } \\
\text { - Tilhænger af øget koordinering. } \\
\text { - Bevarelse af enstemmighed. }\end{array}$ \\
\hline & $\begin{array}{l}\text { Forsvarspolitik og } \\
\text { WEU }\end{array}$ & $\begin{array}{l}\text { - Tilhænger af dansk WEU-medlemskab. } \\
\text { - Udvidelse af FUSP med forsvarspolitik. }\end{array}$ & $\begin{array}{l}\text { - Modstander af dansk medlemskab af WEU. } \\
\text { - Modstander af inklusionen af forsvarspolitikken i FUSP. }\end{array}$ \\
\hline
\end{tabular}

Kilder: Folketingets Forhandlinger 1988/89, spalte 10126ff; 10757ff; Folketingets Forhandlinger 1989/90, spalte 2567ff; 2568; 8455ff; 8460-62; 8473-81; 10126ff; Venstre (1989); Christoffersen (1992); Haahr (1990; 1992; 1993); Laursen (1992); Petersen (2006). 
velegnede til at studere de reelle magtforhold mellem regering og Folketing i den europæiske integrationsproces.

\section{Optakten til Maastricht-forhandlingerne}

I løbet af 1989 og i takt med de dramatiske begivenheder i Østeuropa blev det klart, at EF’s medlemslande så sig tvunget til at indkalde til en ny regeringskonference. Dagsordenen for konferencen ville være at transformere EF til en politisk og monetær union. Dette ville således medføre radikale ændringer i Danmarks relationer til fællesskabet og afgørende ændre dets samarbejdsområder og funktionsmåder. Regeringens og Socialdemokratiets visioner for den danske tilslutning var, på trods af de på overfladen konsensusprægede signaler, præget af mistillid, da der lurede en række uafklarede konflikter under overfladen om karakteren af den danske europapolitik.

\section{Aktørernes preferencer og idealpunkter}

På trods af Socialdemokratiets mere pro-europxiske holdning siden nederlaget i folkeafstemningen i 1986, havde partiet konsolideret sin skepsis imod yderligere integration og dansk deltagelse i den fælles udenrigspolitik samt i forhold til forsvarspolitikken og Vestunionens (WEU) inddragelse i samarbejdet (Petersen 1995). Ligeledes var der udbredt socialdemokratisk modstand imod dansk deltagelse i ØMU'ens tredje fase. De danske reaktioner på udsigten til en ny regeringskonference var tøvende, da man fra politisk side umiddelbart havde svært ved at vurdere ambitionerne for den kommende konference. Der var dog enighed om, at man i modsætning til forhandlingerne om Fællesakten skulle forsøge at fremsætte forslag og deltage aktivt under de kommende forhandlinger for at påvirke forhandlingerne i en for Danmark positiv retning men samtidig også forsøge at markere og forsvare danske positioner (Pedersen 2009). Socialdemokratiet lagde især vægt på at forsvare en række centrale bastioner i partiets europapolitik (Petersen 1995).

Det har været muligt at iagttage delegeringshandlinger på i alt 10 områder i det danske memorandum og $\mathrm{i}$ det efterfølgende forhandlingsudspil (Regeringen 1990; CONF-UP 1777/1/91). Regeringens og Socialdemokratiets præferencer forud for den danske positionsdannelse på de forskellige områder, som indgik i denne delegeringshandling, er vist i tabel 2. Før forhandlingerne var der relativt bred konsensus om indholdet af de danske interesser på spørgsmålet om 'effektivitet i EU's institutioner', subsidiaritet og åbenhed. To forhandlingsområder rummede et lavere niveau af konflikt, nemlig spørgsmålet om en udvidelse af Europaparlamentets kompetencer og spørgsmålet om miljøgarantien samt den sociale dimension. Kulturpolitikken og det vigtige ØMU-spørgsmål faldt under definitionen for præferencekonstellation 3, hvor der herskede uenighed mellem regeringen og Socialdemokratiet. Der herskede ligeledes uenighed om spørgsmålet om WEU og den fælles udenrigspolitik, hvor Socialdemokratiet havde markeret stærk modstand imod at inkludere områderne i samarbejdet og ytret modstand imod dansk medlemskab. På trods af de officielle beskrivelser af optakten til konferencen herskede der således forud for forhandlingerne uenighed mellem regeringen og Socialdemokratiet på en række af de centrale områder og dagsordenspunkter forud for regeringskonferencen.

\section{Fra praferencer til forhandlingspositioner}

Forhandlingerne mellem regeringen og Socialdemokratiet om formuleringen af et dansk memorandum foregik hen over sommeren og frem til starten af oktober 1990, hvor det endelige resultat af delegeringshandlingerne inden for de forskellige områder var blevet forhandlet færdigt mellem parterne.

Forhandlingerne resulterede i en række kompromisser om udformningen af de danske positioner, der i vidt omfang afspejlede socialdemokratiske ønsker og prioriteringer. Dette afspejlede sig i klare socialdemokratiske fingeraftryk på spørgsmålet om den sociale dimension og miljøpolitikken, mens en række af de områder, hvor partiet havde givet udtryk for modstand imod yderligere integration og dansk deltagelse, blev holdt ude af de danske positioner, f.eks. WEU og FUSP (Regeringen 1990). Regeringen accepterede i vidt omfang de socialdemokratiske $ø$ nsker og prioriteringer forud for forhandlingerne og gav ligefrem en række indrømmelser, således at partiet faktisk havde større indflydelse på forhandlingspositionerne end forventet. Dette kunne nærmest tale for et 'demokratisk overskud' på dele af de danske forhandlingspositioner.

\section{Fra positioner til resultater}

Udfaldet af forhandlingerne på den sociale dimension og det miljøpolitiske område lå fortsat tættere på de socialdemokratiske positioner end forventet, men ellers tegnede resultatet af forhandlingerne et varieret billede af de danske fingeraftryk på traktatteksten. Således måtte Danmark acceptere forhandlingsresultater på ØMU'en, WEU og udenrigspolitikken, som lå et stykke fra de danske positioner og udtrykte alle udfald, som lå tættere på eller var identiske med regeringens positioner forud for forhandlingerne og derved lå et stykke fra de socialdemokratiske præferencer forud for forhandlingerne. Forslaget om 'effektivitet i institutionerne' vandt ikke indpas på regeringskonferencerne, og spørgsmålet om subsidiaritet og åbenhed adskilte sig fra de danske positioner. I forhold til spørgsmålet om åbenhed blev resultatet ikke så ambitiøst, som man gerne havde set fra dansk side, ligesom udfaldet af forhandlingerne om en udvidelse af EP's kompetencer 
Tabel 3. Hypoteser, positioner og resultater af Maastricht-traktaten

\begin{tabular}{|c|c|c|c|c|}
\hline \multirow[b]{2}{*}{ Forhandlingsområde } & \multicolumn{2}{|c|}{ Hypoteser } & \multicolumn{2}{|c|}{ Resultater } \\
\hline & $\begin{array}{c}\text { Fuld } \\
\text { information }\end{array}$ & $\begin{array}{c}\text { Asymmetrisk } \\
\text { information }\end{array}$ & $\begin{array}{c}\text { Anlagt } \\
\text { forhandlingsposition }\end{array}$ & $\begin{array}{c}\text { Accepteret } \\
\text { forhandlingsresultat }\end{array}$ \\
\hline Effektivitet i institutioner & $P$ & $S Q$ & $P$ & $S Q$ \\
\hline Subsidaritet & P & $S Q$ & $\mathrm{P}$ & Z (tættere på P end SQ) \\
\hline Åbenhed & $P$ & $S Q$ & $P$ & Z (tættere på P end SQ) \\
\hline Europaparlamentet & A & $S Q$ & A & Z (tættere på A end P) \\
\hline Miliø $\emptyset$ og arbejdsmarkedspolitik & A & $S Q$ & $P$ & $P$ \\
\hline Social dimension & A & $S Q$ & $P$ & $X$ tættere på $\mathrm{P}$ end $\mathrm{A}$ \\
\hline Kulturpolitik & $\varepsilon$ tættere på P end $S Q$ & A & $\varepsilon$ tættere på P end $S Q$ & $\varepsilon$ tættere på $P$ end $S Q$ \\
\hline$\emptyset \mathrm{MU}$ & 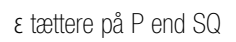 & A & $\varepsilon$ tættere på P end SQ & A \\
\hline Fælles udenrigs- og sikkerhedspolitik & $S Q$ & A & $S Q$ & A \\
\hline Vestunionen & $S Q$ & A & SQ & A \\
\hline
\end{tabular}

Note: $\mathrm{Z}$ udtrykker resultater, som adskiller sig fra modelforventningerne.

blev mindre ambitiøst end det danske udspil (jf. Pedersen 2009).

Samlet må man konkludere, at det endelige resultat lå et godt stykke fra de danske forhandlingspositioner, ligesom de endelige udfald på en række af de 'store' centrale områder som FUSP, WEU og ØMU'en lå tættere på regeringens end på det socialdemokratiske idealpunkt. Omfanget af delegeringstabet på regeringskonferencen var således på en lang række områder højere end forventet. Tabel 3 sammenfatter udfaldet af de danske positioner og viser de resultater, som den danske regering og Folketinget endte med at acceptere efter regeringskonferenceforhandlingerne. ${ }^{8}$

\section{Parlamentarisk afkobling under Maastricht- forhandlingerne?}

Tabel 4 sammenfatter resultatet af analysen og viser, at delegeringstabene især var højere end forventet på FUSP, WEU og ØMU'en, og at der ligeledes kunne observeres et tab på spørgsmålet om effektivitet. Tabellen viser dog samtidig, at tabene var mindre end forventet ud fra specifikationerne i den asymmetriske informationsmodel på de resterende områder.

Analysen tegner et varieret billede af argumentet om parlamentarisk afkobling på indflydelsen af regeringernes forhandlinger i den europæiske integrationsproces, når der tages højde for info-asymmetri. Mens pivotalaktørens indflydelse således er mindre end forventet på en række områder, og udfaldet af disse tilsyneladende kan forklares af modellen, der tager højde for asymmetrisk information, kan den dog ikke forklare udfaldet på andre områder, hvor principalens indflydelse er højere end forventet, hvorfor delegeringstabet er lavere på disse områder, end vi teoretisk skulle forvente.

Ovennævnte korrelationslignende analyse siger i sig selv ikke noget om, hvorvidt der rent faktisk eksisterede 'moral hazard' problemer på de pågældende områder. Generelt viser analysen, at delegeringsudfaldet lå væsentligt tættere på regeringens end på Socialdemokratiets præferencer på en række af de centrale områder, hvilket

Tabel 4. Ændringer i delegeringstab under fuld og asymmetrisk information

\begin{tabular}{|lcc|}
\hline Forhandlingsområde & $\begin{array}{c}\text { Endring i delegeringstab i forhold til } \\
\text { forventninger under fuld information }\end{array}$ & $\begin{array}{c}\text { AEndring i delegeringstab i forhold til } \\
\text { forventninger under asymmetrisk information }\end{array}$ \\
\hline Effektivitet i institutionerne & + & 0 \\
Subsidiaritet & + & - \\
Ábenhed & - & - \\
Europaparlamentet & - & - \\
Miliø- og arbejdsmiljøpolitik & - & - \\
Social dimension & 0 & - \\
Kulturpolitik & + & 0 \\
$\emptyset$ MUU & + & 0 \\
FUSP & + & \\
Forsvarspolitik og WEU & & \\
\hline
\end{tabular}

Note: + angiver et højere niveau af delegeringstab end forventet, - et lavere niveau, og 0 angiver et forventet niveau. 
kunne tyde på, at regeringen gennem manipulering af informationsasymmetrier kunne være i stand til at få sine præferencer igennem. Spørgsmålet er imidlertid, om udfaldet på de enkelte områder kan tilskrives eksistensen af asymmetrisk information mellem principal og agent. Mere kvalitative analyser af delegeringshandlingerne på de enkelte områder vidner om, at der igennem forhandlingerne eksisterede et højt informationsniveau mellem principal og agent (Pedersen 2009: 203-208). ${ }^{9}$ Dette indikerer, at det er vanskeligt at henføre resultaterne til egentlige informationsasymmetrier og regeringsmanipulation af denne. Udviklingen på konferencen pressede i en pro-europæisk retning i form af en relativt ambitiøs traktatudvidelse, som generelt lå uden for de danske positioner, men tættere på regeringens præferencer end de socialdemokratiske grundet de stærke tyske og franske interesser, der var i stand til at rykke dagsordenen for forhandlingerne på konferencen. Dette tvang Socialdemokratiet til at acceptere udfald, som de ellers ikke burde have accepteret forud for forhandlingerne. Der er således ikke noget i den kvalitative analyse, der taler for, at information som kausalmekanisme betinger omfanget af delegeringstab under konferencen. Dette tyder på, at den parlamentariske kontrol med regeringen er velfungerende, hvilket ikke mindst bunder $i$, at den danske mindretalsregering er afhængig af oppositionen for at sikre sig et flertal bag de internationale aftaler, den søger at indgå.

\section{Konklusion}

Analysen af forhandlingerne vidner om, at en række eksterne faktorer har haft afgørende betydning på forløbet af forhandlingerne og på de resultater, de danske partier har måttet acceptere. Information kan derfor måske nok ses som en nødvendig, men ikke tilstrækkelig variabel, når omfanget af de relativt høje deleringsomkostninger skal forklares. Analysen bekræfter, at det danske forhandlingsrum var særdeles begrænset på en række af de helt centrale områder som ØMU'en, FUSP og WEU. Endvidere viser analysen, at de danske muligheder de facto var begrænset til spørgsmålet om, hvorvidt og hvor hurtigt man ville tilpasse sig denne udvikling. Regeringens rolle var generelt at formidle og kommunikere udviklingen til Socialdemokratiet samt finde passende kompensationsområder, der kunne bruges til at sikre socialdemokratisk accept af traktaten. Isoleret set taler dette for, at regeringens autonomi ikke var videre udstrakt, og at den i overvejende grad agerede loyalt over for flertallet i Folketinget. Diskussionen om parlamentarisk afkobling i den danske case vidner om, at det danske folketing - blandt andet pga. traditionen for mindretalsregeringer - generelt havde stor indflydelse på og kontrol med regeringens in- ternationale forhandlingsadfærd. Som følge af Danmarks status i samarbejdet har landet dog oftest ikke indflydelse på at definere dagsordenen og placeringen af reservationspunktet i forhandlingerne, hvorfor Danmark i perioder har måttet acceptere udfald, som ikke var indeholdt i de formulerede positioner. Dette begrænser regeringens mulighed for autonomi, da den indgår i et vanskeligt 'twolevel game', hvor den på den ene side aktivt må søge at tilpasse sig den internationale udvikling og på den anden side videreformidle et troværdigt billede af udviklingen i forhandlingerne for at undgå at få et mindretal imod sig. En øvelse, der til stadighed synes central for de danske regeringer i det europæiske samarbejde.

\section{Referencer}

Anderson, JJ 2002, 'Europeanization and the Transformation of the Democratic Polity, 1945-2000', Journal of Common Market Studies, vol. 40, no. 5, pp. 793-822.

Börzel, T \& T Risse 2006, 'Europeanization: The Domestic Impact of EU Politics', pp. 483-504 in Knud Erik Jørgensen, Mark A. Pollack \& Ben Rosamond (eds), Handbook of European Union Politics, London: Sage.

Christoffersen, SP 1992, Traktaten om Den Europaiske Union baggrund, forhandling og resultat, Jurist- og Økonomforbundets Forlag, København.

CONF-UP 1777/1/91 Danish Proposal at the IGC, 23 March 1991.

Dyson, K \& K Featherstone 1999, The Road to Maastricht: Negotiating Economic and Monetary Union, London: Longman.

The Economist 1991, 'A light is dimmed', 19 January 1991.

Folketingets forhandlinger, div. årg.

Follesdal, A 1998, 'Democracy, Legitimacy and Majority rule in the EU', in A Weale \& M Nentwich (red.), Political Theory and the European Union: Legitimacy, Constitutional Choice and Citizenship, Routledge, London.

Follesdal, A 2000, 'Subsidiarity and Democratic Deliberation', in EO Eriksen \& JE Fossum (red.), Democracy in the European Union: Integration through Deliberation? Routledge, London.

Goetz, K 2005, 'The new Member States and the EU: Responding to Europe', pp. 254-284 in Simon Bulmer \& Christian Lequesne (eds.), The Member States of the European Union, Oxford: Oxford University Press.

Haahr, JH 1990, 'Socialdemokratiets nye EF-politik i integrationsteoretisk belysning', i Dansk Udenrigspolitisk Årbog 1990, Dansk Udenrigspolitisk Institut, Jurist- og Økonomforbundets Forlag, København.

Haahr, JH 1992, 'European Integration and the Left in Britain and Denmark', Journal of Common Market Studies, vol. 30, pp. 77-100.

Haahr, JH 1993, Looking to Europe. The EC Politics of the British Labour Party and the Danish SDP, Aarhus University Press, Aarhus.

Hug, S 2002, Voices of Europe: Citizens, Referendums, and European Integration, Lanham, MD: Rowman and Littlefield.

Hug, S \& T König 2002, 'In View of Ratification: Governmental Preferences and Domestic Constraints at the Amsterdam Intergovernmental Conference', International Organization, Spring, vol. 56, pp. 447-76. 
Kiewiet, DR \& MD McCubbins 1991, The Logic of Delegation, University of Chicago Press, Chicago.

Koenig-Archibugi, M 2004, 'Explaining Governmental Preferences for Institutional Change in EU Foreign and Security Policy', International Organization, 58(1): 137-174.

Laursen, F 1992, 'Denmark and the European Political Union', in F Laursen \& S Vanhoonacker (red.), The Intergovernmental Conference on Political Union Institutional Reforms, New Policies and International Identity of the European Community, European Institute of Public Administration, Maastricht.

Laursen, F (1994a). 'Denmark and the Ratification of the Maastricht Treaty', pp. 61-86 in Finn Laursen \& Sophie Vanhoonacker (eds), The Ratification of the Maastricht Treaty, Maastricht: European Institute of Public Administration.

Laursen, F (1994b), 'The Not-So-Permissive Consensus: Thoughts on the Maastricht Treaty and the Future of European Integration', pp. 295-318 in F Laursen \& S Vanhoonacker (eds), The Ratification of the Maastricht Treaty, Maastricht: European Institute of Public Administration.

Lupia, A 1992, 'Busy Voters, Agenda Control, and the Power of Information', American Political Science Review, vol. 86, no. 3, pp. 90-404.

Lupia, A 2003, 'Delegation and its perils', in K Strøm, WC Müller \& T Bergman (red.), Delegation and accountability in parliamentary democracies, Oxford University Press, Oxford.

Maurer, A \& W Wessels 2001, National Parliaments on their Ways to Europe: Losers or Latecomers? Nomos Verlagsgesellschaft, BadenBaden.

Maurer, A, J Mittag, \& W Wessels 2003, 'National Systems' Adaptation to the EU System: Trends, Offers, and Constraints', pp. 53-81 in Beate Kohler-Koch (ed.), Linking EU and National Governance, Oxford: Oxford University Press.

Moravcsik, A 1993, 'Preferences and Power in the European Community: A Liberal Intergovernmentalist Approach', Journal of Common Market Studies, vol. 31, no. 4, pp. 473-524.

Moravcsik, A 1998, The Choice for Europe. Social Purpose and State Power from Messina to Maastricht, University College London Press, London.

Niskanen, WA 1971, Bureaucracy and Representative Government, Aldine-Atherton, Chicago.

Pedersen, RB 2009, Danmark under traktaterne Et case studium af regerings- og parlamentsrelationerne under forhandlingerne om Falles Akten og Maastricht-traktaten, Politica, Århus.

Petersen, N 1991, EF, den politiske union og Danmark analyse og dokumentation, København: Det sikkerheds- og nedrustningspolitiske udvalg.

Petersen, N 1995, 'Denmark and the European Community 19851993', pp.189-224 in Nikolaj Petersen \& Carsten Due-Nielsen (eds), Adaption \& Activism the Foreign Policy of Denmark 1973-1993, Copenhagen: Dansk Udenrigspolitisk Institut, DJØF Publishing.

Petersen, N 2006, Europaisk og globalt engagement 1973-2006, Bind 6, Dansk Udenrigspolitisk historie, Gyldendal, København.

Poguntke, T \& P Webb (red.) 2005, The Presidentialization of Politics: A Comparative Study of Modern Democracies, Oxford University Press, Oxford.
Raunio, T 1999, 'Always One Step Behind? National Legislatures and the European Union', Government and Opposition, vol. 34, no. 2, pp. 180-202.

Raunio, T 2005, 'Holding Governments Accountable in European Affairs: Explaining Cross-National Variation', Journal of Legislative Studies, vol. 11, no. 3-4, pp. 319-42.

Raunio, T \& S Hix 2000, 'Backbenchers Learn to Fight Back: European Integration and Parliamentary Government', West European Politics, October, vol. 23, no. 4, pp. 142-68.

Regeringen 1990, Det danske regeringsmemorandum af 4. oktober 1990.

Romer, T \& H Rosenthal 1978, 'Political Resource Allocation, Controlled Agendas, and the Status Quo', Public Choice, vol. 33, pp. 27-44.

Strøm, K 2000, 'Delegation and Accountability in Parliamentary Democracies', European Journal of Political Research, vol. 37, no. 3, pp. 261-89.

Thomson, R, FN. Stokman, CH Achen \& T König 2006b, The European Union Decides, Cambridge University Press.

\section{Noter}

1. Modellen er inspireret af Lupia (1992), Niskanen (1971) samt Romer \& Rosenthal (1978).

2. Lignende problemstillinger diskuteres i den rational choice-inspirerede forhandlingslitteratur jf. Koenig-Archibugi (2004); Hug (2002); Hug \& König (2002); Thomson et al. (2006).

3. Effekten af adverse selection er ikke berørt i modellen.

4. Modellen inkluderer således ikke antagelser om issue linkages og log rolling mellem de forskellige områder.

5. Andre præferencekonstellationer kunne selvsagt formuleres.

6. Regeringsmemorandummet af 1990 var på trods af sit navn et produkt af en forhandlingsproces mellem regering og Folketing, herunder særligt Socialdemokratiet og det Radikale Venstre. Se Pedersen 2009: 134-138 for en detaljeret beskrivelse. Der indgik flere områder i det danske udspil, men de vil ikke blive analyseret her, da der mangler detaljerede beskrivelser af aktørernes positioner på disse områder.

7. For en udførlig diskussion af data se Pedersen 2009: 47-50.

8. Det skal bemærkes, at analysen ikke inkluderer forhandlingerne efter den fejlslagne danske ratificering, som mundede ud i Edinburghaftalen.

9. Der kan observeres et enkelt forsøg på 'moral hazard' fra regeringens side i forhandlingerne om FUSP og spørgsmålet om WEU's inddragelse i samarbejdet. Regeringen forsøgte tilsyneladende at foretage handlinger, som adskilte sig fra de mandater, den medbragte fra det danske memorandum (jf. Economist 1991). Regeringens forsøg på at rykke dagsordenen på dette område medførte en stærk socialdemokratisk reaktion, hvor man kraftigt understregede, at regeringen skulle fremføre mere SQ-orienterede standpunkter. 